\title{
コリデール種緬羊の毛胞群に関する研究
}

II 仔緬羊の発育に伴う毛胞群の変化についで

菅 井一男

（京都工芸瀻維大学縰維学部）

Studies on the hair follicle population in the Corriedale sheep

II On the changes of the hair follicle population in relation to lamb growth

\section{KAZUO SUGAI}

(Faculty of Textile Fibers, Kyoto Technical Tiniversity)

\section{I 緒言}

著者は，第1報において，コリデール種仔緬羊皮肤の 毛胞群について，其の一般組織学的形態，毛胞の種類と 皮肤附属腺との関係，生媵の毛胞群の形成，毛胞群より の脱毛等について報告したが，本研究は，コリデール種 丹糆羊の生後の発充飞偻う毛胞群の変化, 特飞毛胞の密 度, 毛束 (follicle bundle) の密度及び毛胞の大いさの変 化る知るために，これら各々について，個体別：体部位 別，生後の月令別に测定し，此较検詰したものである。

\section{II 実験の材料と方法}

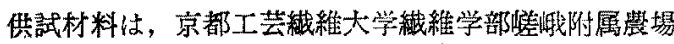
1951年春季生産のコリデール種仔緬羊 4 頍（䊒3，雄1） である。供試仔䋗羊は，何れる奏験期間中舎飼を行い， 生後約 3 ケで離乳せしめたものであり，其の栄蕞状態 は，中等であつて，普通の発有を示した。皮肤組織㩐本 の作製については，これら甘緬羊の生挠1ヶ月，3ケ月， 6ケ月及ざ9ケ月において，其の生体の肩，脇腹，腿の 3 部位より，約 Isq. $\mathrm{cm}$. 0 皮肤小片を切除し，て礼ら。 を直らに, formol saline で固定, paraffin-wax 混合物 で包裡し，皮肤表面に平行なる組織標本を作彆した。な 朽標本の染色に法，WEIGERT's Iron Haematoxylin 及び VAN GIESON 染色を用い。又毛胞の密度，毛束の密度 及び毛胞の直径の測定には，出来得る限り第】次毛胞に 附属する皮脂腺が存在する皮肤の樑さから得られた，破 損しない，完全な皮肤切片を選定し，なお毛胞の密度 (皮肤の $1 \mathrm{sq} . \mathrm{mm}$. 当り口毛胞数) は, $0.5 \times 0.5 \mathrm{~cm}$. ○接眼利状々クロメ゙ータ一艺使用し, section paper 上 に毛胞群の㫕取図を画いて算出した。

\section{III 実験の成績と考祭}

\section{（1）毛胞の密度の装化}

毛胞の密度は， 1 毛束当りの毛胞数，単位面積当りの 毛胞数の而者に区分して考察し，こ礼各々の变化を調 ベだ。

(a) 1 毛束当りの毛胞数の留化 各供試任緬羊の生

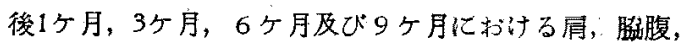
䬤 3 部位の 1 毛束当り，の毛胞数を算定した成績它示す と，第 1 表の通りである。第 1 表の如々， 1 毛束当りの 第 1 表 毛胞の篦度の答化

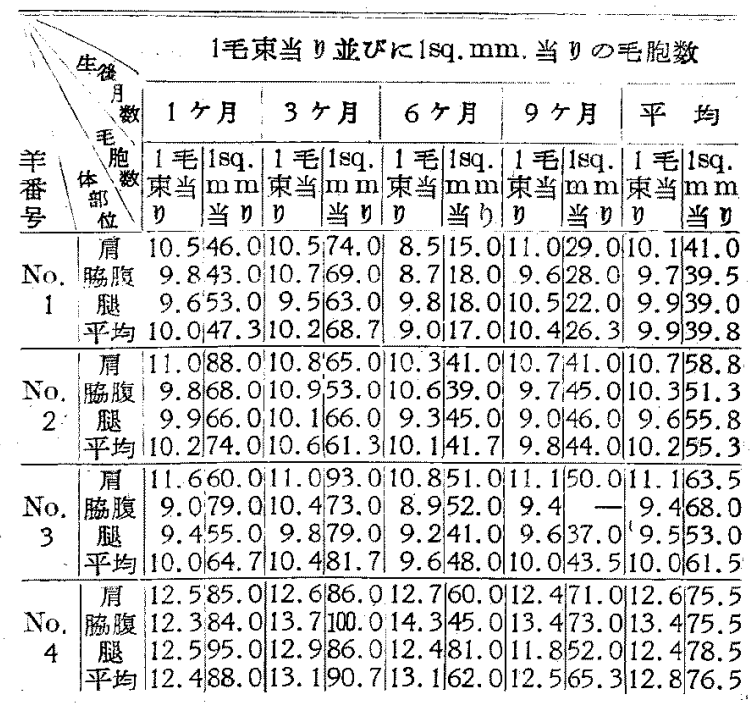

備考 No.3脇腹 9 ケの $1 \mathrm{sq} . \mathrm{mm}$. 当りの毛胞数は，適 当なる組䄳㯲本が得らすず，測定し得なかつた。

毛胞数は，個体，体部位，又生後の経過月令により，其

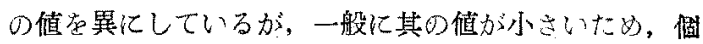
体，体部位及び生後の月命による善は，罝だ小てある。 即ち個体の1毛束当りの毛胞数の平均は，9.9より12.8迄 の範囲にあり，各個体の体部位別平均毛胞数字，No.4

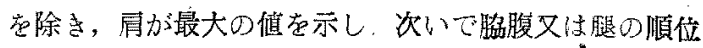
でする。 
各個体の月令別の平均毛胞数は，No. 1 の場合范除き， 生後3ケ月において最大の值を示し，生後6ケ月にわい ては, 稍々涐少し，生後9ケ月に打いては，生後6ケ月 に近い値を示している。

（b） 単位面檟当りの毛胞数の变化 各供訊仔緬弚の 生後士ケ月，3ケ月，65月，及び9ケ月に打ける局，脇

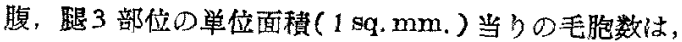
第1表に示す通りである。本表によれば，1 sq. mm. 当 りの琶胞数は，（a）の場合之同様化，個体，体部位， 又生後の月令により，其の值を異にしているが，一般に 其の值が大き?，従つて個体，体部位及び生後の月令に よる差は，（a）の場合に比挍して各々大である。即ち個 体の平均毛胞数は，40より77迄の範围にあり，体部位別 平均毛胞数は, 個体に上り肩, 胳腹又は脚において最大 となり，体部位間の毛胞数の大小に，一定の順位が見ら れない。又個体の月令別平均毛胞数は，No.2 の場合を 除き，他何れも生後3 ケ月に利いて最大となり，生後 6ケ月に珖いては相当著しい減少が見られ，生後9ケ月 においては，No.3 の場合を除き，他は何れも，生後 6 ケ月の嚗合よりも增加を示しているが，な和其の数は， 生後1ケ月の数に比䡆してかなりの減少を示している。 毛胞の密度の生後の月令による恣化は，仔緬羊の成长に 伴ら皮肤面積の增大を考慮すべきであるが，皮肤面積の 增大を考應するとしても，生挠3ケ月支中心として，新 しい第 2 次毛胞の生座, 若命の第 2 次毛胞の成長が見ら れるため，毛胞の密度は，生後3ケ月にわいて最大之な り生後6ケ月を中心こして, 毛胞群上り多数の脱毛を生 ずるため，生後6ケ月において特に毛胞の密度が減少す るものと考光られる。

（2）毛束の密度の変化

毛束の密度の变化については，单位面積 (1 sq. mm.) 当りの毛束数测定して，其の変化䛏調べた。然し毛束 の密度は，毛束間の境界が明膫ではいすのが多了，毛束 数の正確な算定が困難であつたため，第 1 表に示した 1 sq. mm. 当りの毛胞数を 1 毛束当りの毛胞数で除した商 它以て，毛束の密度とし，其の数值を示せ代，第 2 表の 通りである。本表によれば，毛柬の密度（1 sq. mm，当 りの毛束数）も，個体，体部位，個体生後の月令により， 其の值を買にしているが，一般に $1 \mathrm{sq} . \mathrm{mm}$. 当りの毛束 数が小さいだ，其の差は僅少である。即ち個体の毛束 数の平均は，4.1よb6.0迄の值を示し，体部位別平均毛 束数は，個体により局，脇腹又住眼において最大を示し 体部位問の毛束数の大小に，一定の順位を示さない。文 各個体の生後の月令による $1 \mathrm{sq} . \mathrm{mm}$. 当りの平均毛束数 の翌化については，生後1ケ月又は 3 ケ月において，毛 束数は，最大の値在示し，其の後は減少を示し，生後 9
第 2 表 毛束の滵度の変化

\begin{tabular}{|c|c|c|c|c|c|c|}
\hline \multirow{2}{*}{\multicolumn{2}{|c|}{ 体阯位月 }} & \multicolumn{5}{|c|}{$1 \mathrm{sq} . \mathrm{mm}$, 当り口毛胞数 } \\
\hline & & はケ月 & 3ケ月 & 6 兵月 & 9ケ月 & 平均 \\
\hline No. 1 & 嵒 ${ }^{\text {平腹 }}$ & $\begin{array}{l}4.4 \\
4.4 \\
5.5 \\
4.8 \\
\end{array}$ & $\begin{array}{l}7.0 \\
6.4 \\
6.6 \\
6.7 \\
\end{array}$ & $\begin{array}{l}1.7 \\
2.1 \\
1.8 \\
1.9 \\
\end{array}$ & $\begin{array}{l}3.8 \\
2.9 \\
2.1 \\
2.9 \\
\end{array}$ & $\begin{array}{l}4.2 \\
4.0 \\
4.0 \\
4.1\end{array}$ \\
\hline No. 2 & & $\begin{array}{l}8.0 \\
6.9 \\
6.7 \\
7.2 \\
\end{array}$ & $\begin{array}{l}6.0 \\
4.9 \\
6.5 \\
5.8 \\
\end{array}$ & $\begin{array}{l}4.0 \\
3.7 \\
4.8 \\
4.2\end{array}$ & $\begin{array}{l}3.8 \\
4.6 \\
5.1 \\
4.5\end{array}$ & $\begin{array}{l}5.5 \\
5.0 \\
5.8 \\
5.4\end{array}$ \\
\hline No. 3 & 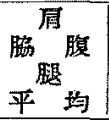 & $\begin{array}{l}5.2 \\
8.8 \\
5.9 \\
6.6 \\
\end{array}$ & $\begin{array}{l}8.5 \\
7.0 \\
8.1 \\
7.9 \\
\end{array}$ & $\begin{array}{l}4.7 \\
4.7 \\
4.5 \\
4.6\end{array}$ & $\begin{array}{l}4.5 \\
3.9 \\
4.2\end{array}$ & $\begin{array}{l}5.7 \\
6.8 \\
5.6 \\
6.0\end{array}$ \\
\hline & 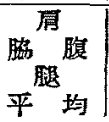 & $\begin{array}{l}6.8 \\
6.8 \\
7.6 \\
7.1\end{array}$ & $\begin{array}{l}6.8 \\
7.3 \\
6.7 \\
6.9\end{array}$ & $\begin{array}{l}4.7 \\
3.1 \\
6.5 \\
4.8\end{array}$ & $\begin{array}{l}5.7 \\
5.4 \\
4.4 \\
5.2\end{array}$ & $\begin{array}{l}6.0 \\
5.7 \\
6.3 \\
6.0\end{array}$ \\
\hline
\end{tabular}

ケ月にわいては，No.3の場合を除き，生後6ヶ月の場 合よりも，增加の㖽向現られるが，9ケ月の值は，生 後1ケ月の值よりも小である。

(3) 毛胞の夫さの変化

第 1 次毛胞 (primary folliele) 亿附属する皮脂腺が存 在する皮肤の深さにおける第 1 次並びに第2次毛胞（Se-

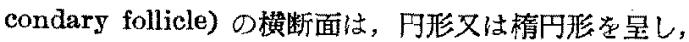
其の直径（椐円形の場合は長径）は，各毛胞発生時期の 早晚により，其の大さを異にするが，乙れら第1次並び に 2 第次毛胞の直径の值の生後の月令別変化走示せば， 第3表の通りである。

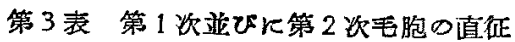
(单位 $\mu$ ) の婆化

\begin{tabular}{|c|c|c|c|c|c|}
\hline \multirow{3}{*}{ 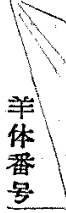 } & \multicolumn{5}{|c|}{ 第 1 次及ひ第 2 次气胞の直征 } \\
\hline & 1ケ月 & 3ケ月 & 6ケ月 & 9 ケ月 & 平均 \\
\hline & 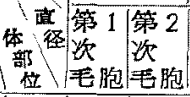 & 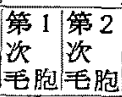 & 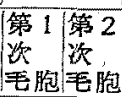 & 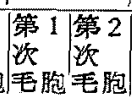 & 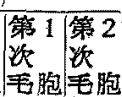 \\
\hline No. & \begin{tabular}{|c|c|c|} 
局 & 48.4 & 40.7 \\
嵒腹 & 41.8 & 33.0 \\
腿 & 48.439 .6 \\
平均 & 46.237 .8 \\
\end{tabular} & 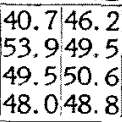 & 46.239 .6 & $547.3 \mid 40.7$ & $\begin{array}{l}45.7 \mid 41.8 \\
50.9 \\
48.4\end{array}$ \\
\hline $\begin{array}{c}\text { No. } \\
2\end{array}$ & 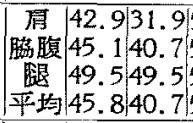 & 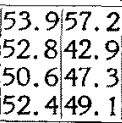 & $\begin{array}{l}45.139 .6 \\
48.4\end{array}$ & \begin{tabular}{|l|l|}
45.1 & 38.5 \\
46.2 & 38.5 \\
40.7 & 36.3 \\
\end{tabular} & \begin{tabular}{l|l|l|}
46.8 & 41.8 \\
48.1 & 39.9 \\
46.5 & 42.6
\end{tabular} \\
\hline $\begin{array}{c}\text { No. } \\
3\end{array}$ & 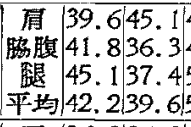 & $\begin{array}{l}44.042 .9 \\
49.546 .2 \\
59.451 .7\end{array}$ & $46.2 \mid 34.1$ & \begin{tabular}{|l|l|}
42.9 & 35.2 \\
45.1 & 40.7 \\
49 & 35
\end{tabular} & \\
\hline $\begin{array}{c}\text { No. } \\
4\end{array}$ & 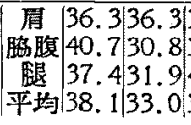 & $\begin{array}{l}31.942 .9 \\
37.4 \\
47.351 .2 \\
47.3\end{array}$ & $451 / 41$ & & \\
\hline
\end{tabular}

本表によれば，第 1 次並びに第 2 次毛胞の賞経も，個 体，体部位，又個体生後の月令により，其の值異にし ている。期方各個体の3 部位における第1次亚びに第 2 
次北胞の百経は，一般に胡腹又は眼にもういて，大であり，

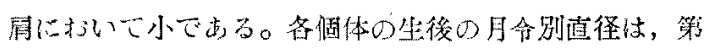
1 次毛胞については，生後3ケ月又は6ケ月に打いて，

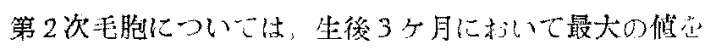
亦し，其の後は娍少の傾问为見られる。

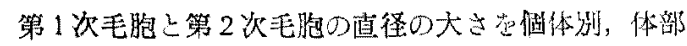
位別並びに生後の月令别に比輁するこ，一般に第 1 次毛

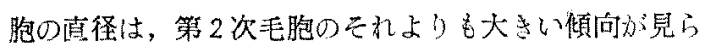
れる。(部文附図参照)

\section{IV 総 括}

本研究は、コリデール種仔緬羊の発肖に伴ら皮肤の毛 胞群の変化を調べるため纪実施したものである。供試材

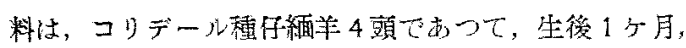

3ケ月，6ケ月，及び9ケ月において，各保緬羊生体の

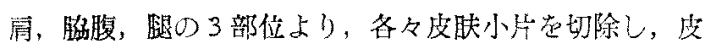

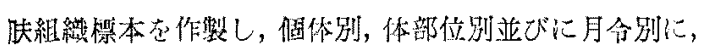
毛胞の密度，毛柬の密度及び毛胞の直径を測定し，てれ らの留化它比較検封した。

其の結果を要約すると次の通りである。

（1）コリデール硾仔緬羊皮肤の毛胞及び毛束の嘧洨

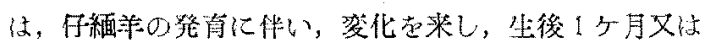
3ケ月において，最大の做に迨し，生後1ケ月又は3ケ 月以降 9 ケ迄は，娍少の傾向が見られる。

（2）毛胞及プ毛束の密度の体部信間の大小は，相体 により異なり，体部位間に一定の順位が見られない。

（3）毛胞の大さ（或径）は，個体、体部位及心生後

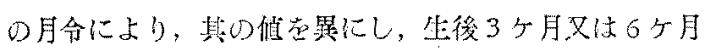
に括てて，最大已なり，其の後 9 力月迄心，堿少な示

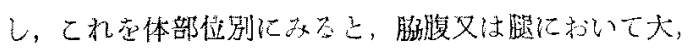
肩において小なる値党示す。

（4）第 1 次毛胞々第 2 次毛胞の直俻の大き学体部位

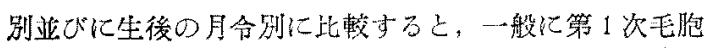

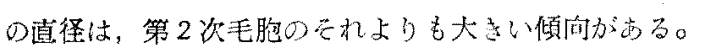

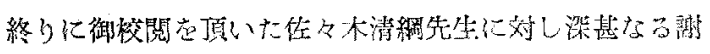

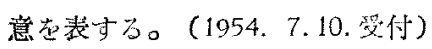

\section{文献}

1) M. Burns (1949): J. Agric. Sci,39, (1)

2) H. B. Carter (1939): J. Coun. Sci. Ind. Res, 12, (3)

3) H. B. CARTER (1943) : Bull. Coun. Sci. Ind. Res., 164
4) II, H. Carter \& Margaret H. Hardy (1947): Bull. Coun. Sei. Ind. Res, 215

5) E. C. Clayden (1948): Practical Section Cutting and staining.

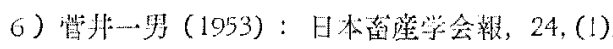

\section{Résumé}

The present study has been carried out to observe changes of the hair follicle population in the Corriedale sheep skin in relation to lamb growth. The animals examined were 4 Corriedale lambs and a small patch of skin was taken from the shoulder, side and the thigh region of each lamb at 1, 3, 6, and 9 months after birth. Wach skin sample was prepared histologically and the differences of the follicle densities, of the follicle bundle densities and of the diameters of the follicles due to different individuals and also to different budy regions and agres of lambs, were studied.

The results obtained were as follows;

(1) The follicle density and the follicle bundle density in the skin of Corriedale sheep were fom to vary according to ages of tamls. The maximm values of density were observed at 1 month or 3 months of age and the decreased values after these months until 9 months after birth.

(2) The relative values of the follicle density and the follicle bundle density in different body regions of lambs differed in different individuals and of definite order in the values was found.

(3) The mean diameters of the follicles varied according to individuals, to body regions and also to ages of lambs. They showed the highest values at 3 or 6 months after birth, and the decreased values after these months until 9 months after birth.

The larger diametors were fornd at the side or thigh region, and the smaller at the sloulder regi(1).

(4) When the diameters of the primary follicles were compared with those of the secondary follicles of different body regions and also of different ages after birth, at tendency that the former was larger than the latter was observed, 


\section{菅 井論 文 附 図}

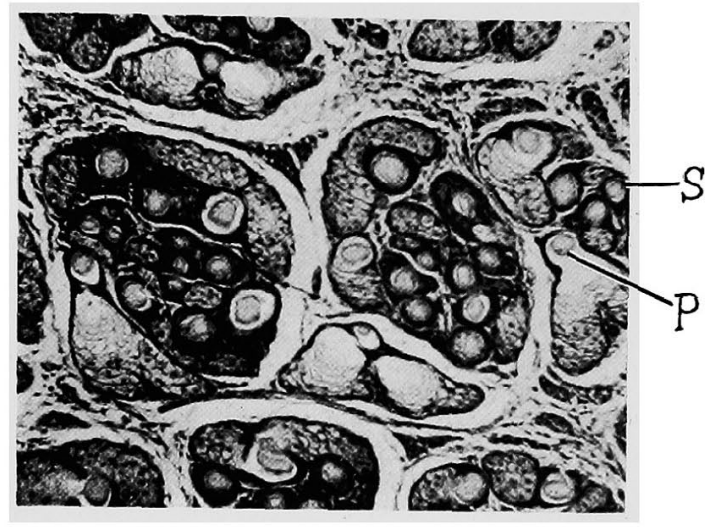

Fig. 1.

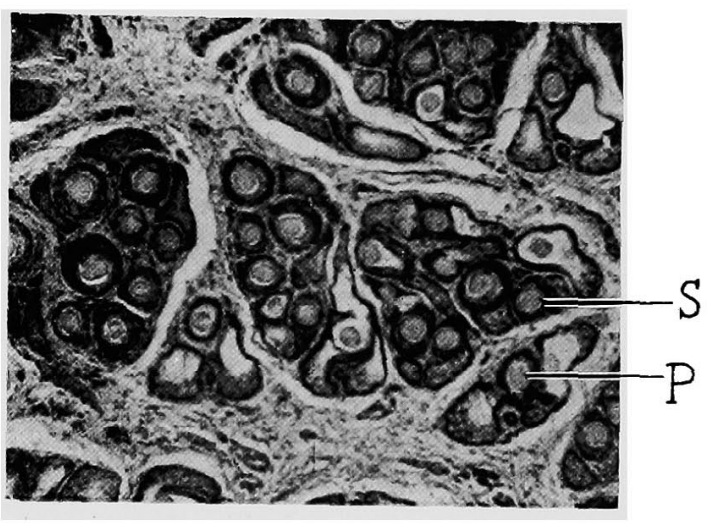

Fig. 3.

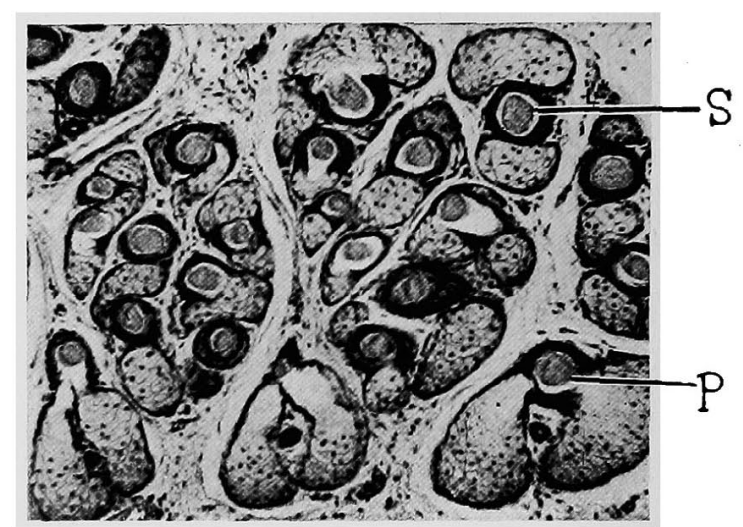

Fig. 2.

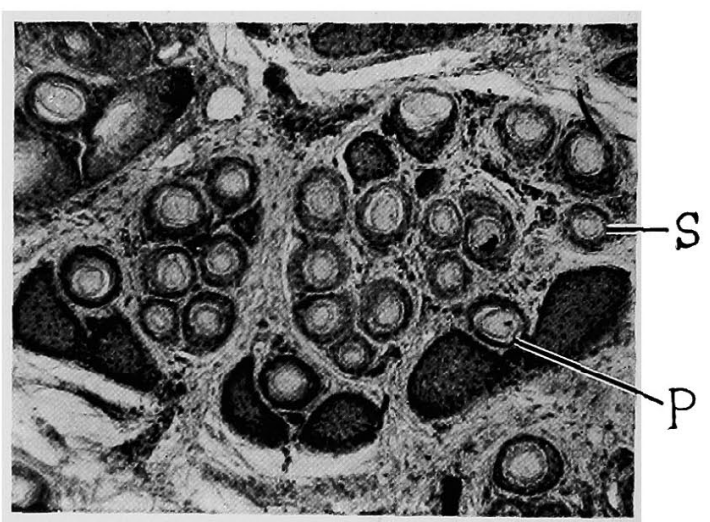

Fig. 4.

Explanation of Figures

Showing age changes of follicle population as seen in horizontal sections of skin from Corriedale sheep.

all $\times 100$.

Fig. 1. Lamb at 1 month of age.

Fig. 2. Lamb at 3 months of age.

Fig. 3. Tamb at 6 months of age.

Fig. 4. Lamb at 9 months of age.

P : Primary follicle, S : Secondary follicle 